\title{
Farewell to print
}

NPS MedicineWise has decided that Australian

Prescriber will not be printed after June 2016.

Publication of the journal will continue online through a newly constructed NPS MedicineWise website (nps.org.au/australianprescriber).

As the Editorial Executive Committee has to say farewell to hard copy, it has been reflecting on the history of the printed journal. Much has changed since Australian Prescriber was first published in 1975. 'Back then, the annual cost of the Pharmaceutical Benefits Scheme was approximately $\$ 270$ million. It has now grown to nearly $\$ 10$ billion and the general patient copayment has risen from $\$ 1.50$ to $\$ 38.30$.

Since 1975 there have been 39 volumes and 190 issues of Australian Prescriber. To discuss the content of these issues, the Editorial Executive Committee has held 310 meetings.

Australian Prescriber was first published by the Australian Government Publishing Service. Initially there were four issues of the journal each year. There was a missing issue in 1977 and print publication was halted in mid-1982. Thanks to lobbying by the Executive Editorial Board, publication resumed again in 1983 with the support of the then Federal Minister of Health (see Fig. 1). Originally each volume was individually indexed. From 1990 a five-year cumulative index was published each year. There will be no index in the new online journal.

In 1999, as there was increasing recognition of the importance of independent information in the quality use of medicines, production of Australian Prescriber was increased to six issues per year. The National Prescribing Service (now known as NPS MedicineWise) took over responsibility for the publication of Australian Prescriber in 2002. It renamed the Executive Editorial Board as the Editorial Executive Committee.

During the past four decades there have been 10 cover designs. Common elements in many designs are medicines and the eye of the Horus. Paper from sustainable sources has been used since 2009.

Australian Prescriber is read by a wide range of health professionals (see Fig. 2). In 2014, a national survey found that more than $96 \%$ of health professionals were aware of Australian Prescriber and more than $87 \%$ were readers of the printed journal.

While the overseas distribution of the printed journal ceased in December 2009, the domestic distribution has been relatively stable at around 53000 copies.
The Editorial Executive Committee therefore believes that Australian Prescriber had the largest circulation of any medical journal in Australia.

Reading Australian Prescriber online is nothing new. In the 1990s the members of the Executive Editorial Board were enthusiastic early adopters of the internet. It is now 20 years since Australian Prescriber became one of the first medical journals to be published online. Readers have been able to choose whether to access the journal's content electronically, via print, or both. However, NPS MedicineWise is now directing resources towards electronic access and is therefore discontinuing print publication. ${ }^{2}$

\section{Australian Prescriber Editorial Executive Committee}

\section{Keywords}

Australian Prescriber medical journal

Aust Prescr 2016;39:103-4

http://dx.doi.org/10.18773/ austprescr.2016.043

\section{Fig. 1 Letter to readers from the Minister for Health, 1983}

Minesteph non HeaLTh Parilarent holse, CANDERRA A.C.T. 2600

Dear Reader,

'Australian Prescriber' was Lirst pub1ished in late 1975 as an independent review of therapeutics and discontinued in 1982 by the previous Governeent as an economy measure. During this period the journal gained an international reputation for its high quality. Since no conparable alternative publication is availablo, I have decided that my Departaent should resume yer and

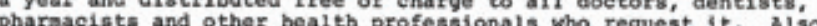
included on the distribution ist will be undergraduates in their final year of medicine, dentistry and pharmacy.

I believe 'Australian Preseriber' is the only publication which comments specifically on drugs approved for marketing in Australia and as sueh provides infornation most relevant for the busy practitioner. The need for such information is highlighted by the fact that my Department, on the advice of the Austrailian Drug Evaluation Committee, approves approximately 20 new drugs each year. In addition, some 20 new presentations of al ready marketed drugs are also approved. This inevitably leads to pronotion of both new and old drugs and the task of praetitioners in selecting the nost appropriate treatment is made more difficult. contained in . Australian prescriber, ind objective information value.

While 'Australian Preseriber' will cost approximately $\$ 150000$ per year, this should be considered in the context of a bill of about $\$ 450000000$ a year for drugs prescribed under the Pharmaceutical Benefits Schome. I believe therefore that the minimal cost involved in produeing the journal is justified since it is expected to lead to the nore appropriate use of drugs and associated decrease in the drug bill and adverse effects.

Although Government funded, 'Australian Prescriber' is an independent review since its Executive zditorial Board is made ap of prominent medical practitioners from the fields of modicine, general practice, clinical pharmacology and psychiatry. In givin are generousiy their confidence and wish 'Australian Preseriber' continuing success in meeting your needs.

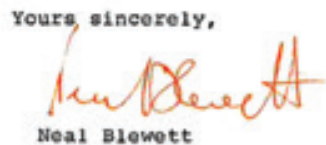


Australian Prescriber has already achieved significant milestones in electronic publishing. It has been listed in the Directory of Open Access Journals since 2003. The journal has been freely available online since 1996 and open access will continue after the cessation of print publication. A website for mobile devices was established in 2013. The first Australian Prescriber smartphone app, The Doctor's Bag, was launched in mid-2015. Readers have been able to follow the journal on Twitter @AustPrescriber since 2012.

In late 2015, Australian Prescriber was accepted for inclusion in PubMed Central. Digital object identifiers are now assigned to all articles published in the journal, enhancing scholarly citation. ${ }^{3}$

Each month more than 200000 people visit the Australian Prescriber website. More than 22000 readers already subscribe to email alerts to be notified of the publication of each new issue, and of material published between issues (online first) such as comments on new drugs.

The Editorial Executive Committee of Australian Prescriber encourages readers of the printed journal to visit the new website at nps.org.au/ australianprescriber. It is our intention that Australian Prescriber will remain a free, independent publication providing open access information about drugs and therapeutics to busy health professionals. $\varangle$
Fig. 2 Australian print categories for April 2016

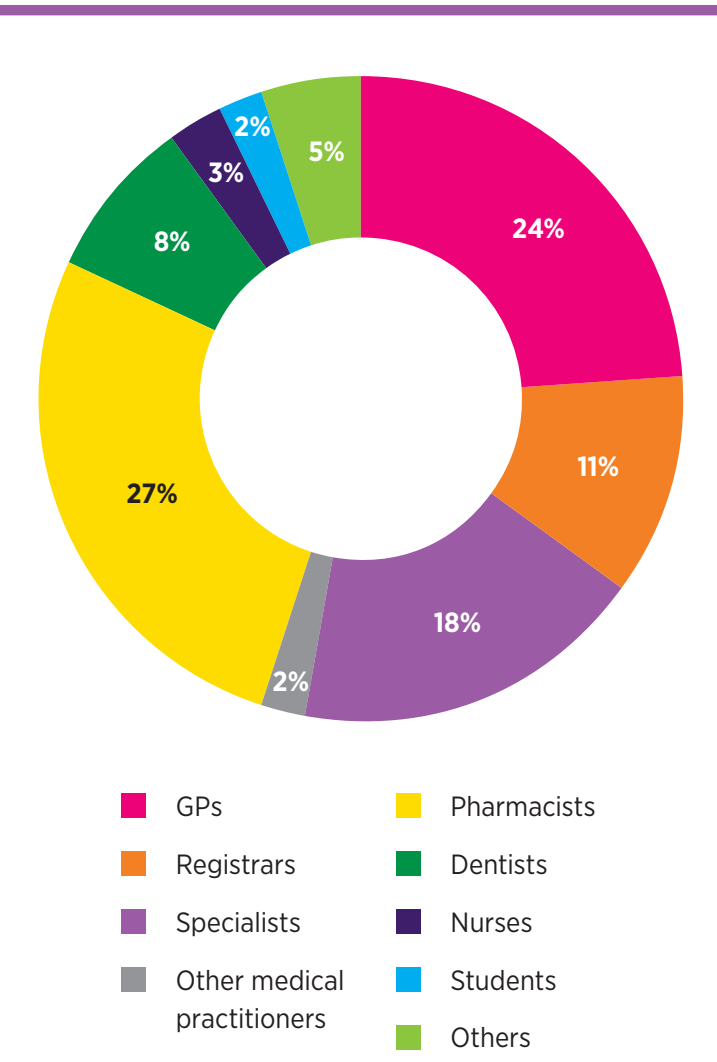

\section{REFERENCES}

1. Dowden J. Forty and forward? Aust Prescr 2015;38:146-7. http://dx.doi.org/10.18773/austprescr.2015.053

3. Exciting things happening in the digital space. Aust Prescr 2016;39:13. http://dx.doi.org/10.18773/austprescr.2016.012

2. Weekes L. The NPS MedicineWise vision for Australian

Prescriber [editorial]. Aust Prescr 2016;39:70-1.

http://dx.doi.org/10.18773/austprescr.2016.042

\section{Examples of Australian Prescriber front covers from the past}
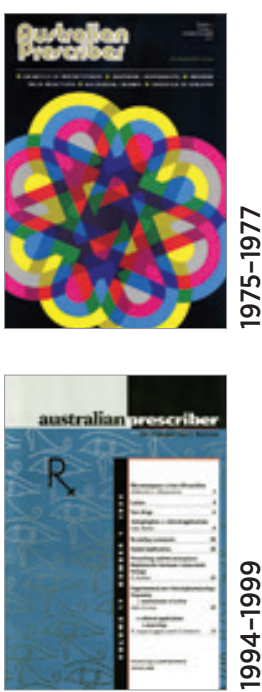
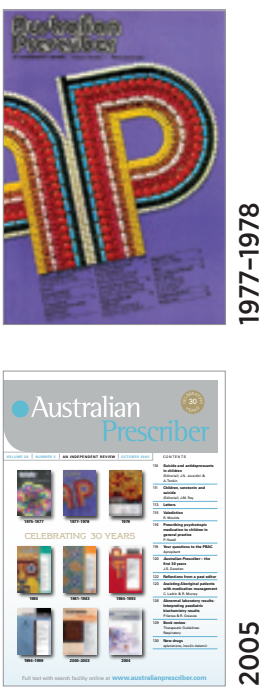

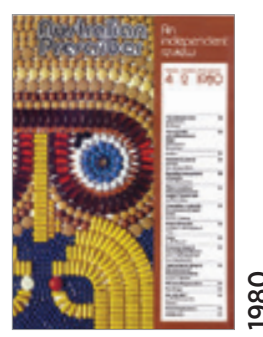

잉

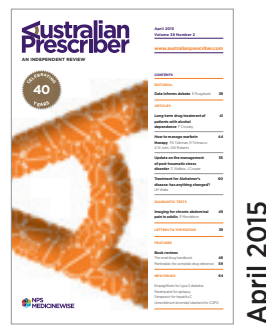

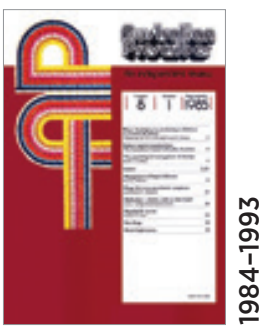

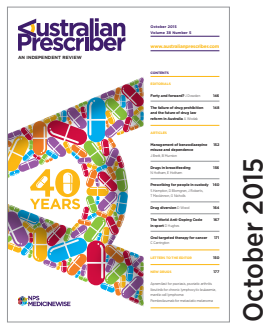

